\title{
Magnetic Stratigraphy of Lake Michigan Sediments Obtained from Cores of Lacustrine Clay
}

\author{
ICARO Vitorello AND ROB VAN DER VOO \\ Department of Geology and Mineralogy, University of Michigan, Ann Arbor, Michigan 48109
}

Received August 23, 1975

\begin{abstract}
Postglacial and lacustrine-sediments from Lake Michigan have been paleomagnetically investigated. The primary goal was to test the feasibility of correlation between several cores in terms of their magnetic signatures. After alternating field and thermal demagnetizations, inclination and relative declination values were obtained that show characteristic short-term fluctuations. Major features, including changes in the magnetic intensity of the samples, correlate well in three of the longer cores, in good agreement with independent lithostratigraphic determinations. In addition, we have been able to detect local disconformities that appear as interruptions of the magnetic record. A continuous record of normal polarity has been found, extending from the present day to $13,000{ }^{14} \mathrm{C}$ vears BP. No reversals were recorded, though at two stratigraphic levets shallow inclinations, to may indicate rapid geomagnetic excursions. The magnetic record was attained at the time of deposition or shortly thereafter, and can be used for a wide range of applications.
\end{abstract}

\section{INTRODUCTION}

The chronological geomagnetic secular variation recorded in the sediments of Lake Michigan has been studied in order to extend the record of the Holocene and late Pleistocene magnetic fie $\widetilde{c o}$ that stratigraphFe correlation would be possible within the Great Lakes region. This record is also useful for comparisons of the geomagnetic field recorded in deep-sea cores and other lakes, and will provide more information for an eventual analysis of the late Quaternary magnetic field.

Detailed variations of the earth's magnetic field have been recorded by direct observations during the past 500 years and have been extended by archeomagnetic investigations and paleomagnetic studies of deep-sea sediments. Since lake sediments may have been deposited more rapidly, lacustrine clays could provide a magnetic record with a much better resolution.

The cores studied were obtained from the southern part of the lake and from sites north of the mid-lake shallow area
(Fig. 1), and they penetrate lacustrine, postglacial, and glacial sediments which cover the bedrock relief, scoured by glaciers.

While the present paper was under review, a similar study was published by Creer et al. (1976). Because of difference in core locations, the present paper complements their study, since the bulk of our sediments are from somewhat older formations.

\section{GEOLOGY: SETTING, HISTORY, AND LITHOLOGY}

Lake Michigan is located on the western flank of the Michigan structural basin where Paleozoic sediments rest on Precambrian rocks. A thin mantle of unconsolidated glacial and postglacial deposits overlies the Paleozoic formations.

During the last substages of the Wisconsinan Stage, a sequence of retreats and readvances of the ice front left the lake basin covered by tills that are progressively younger to the northeast. According to present-day interpretations based 


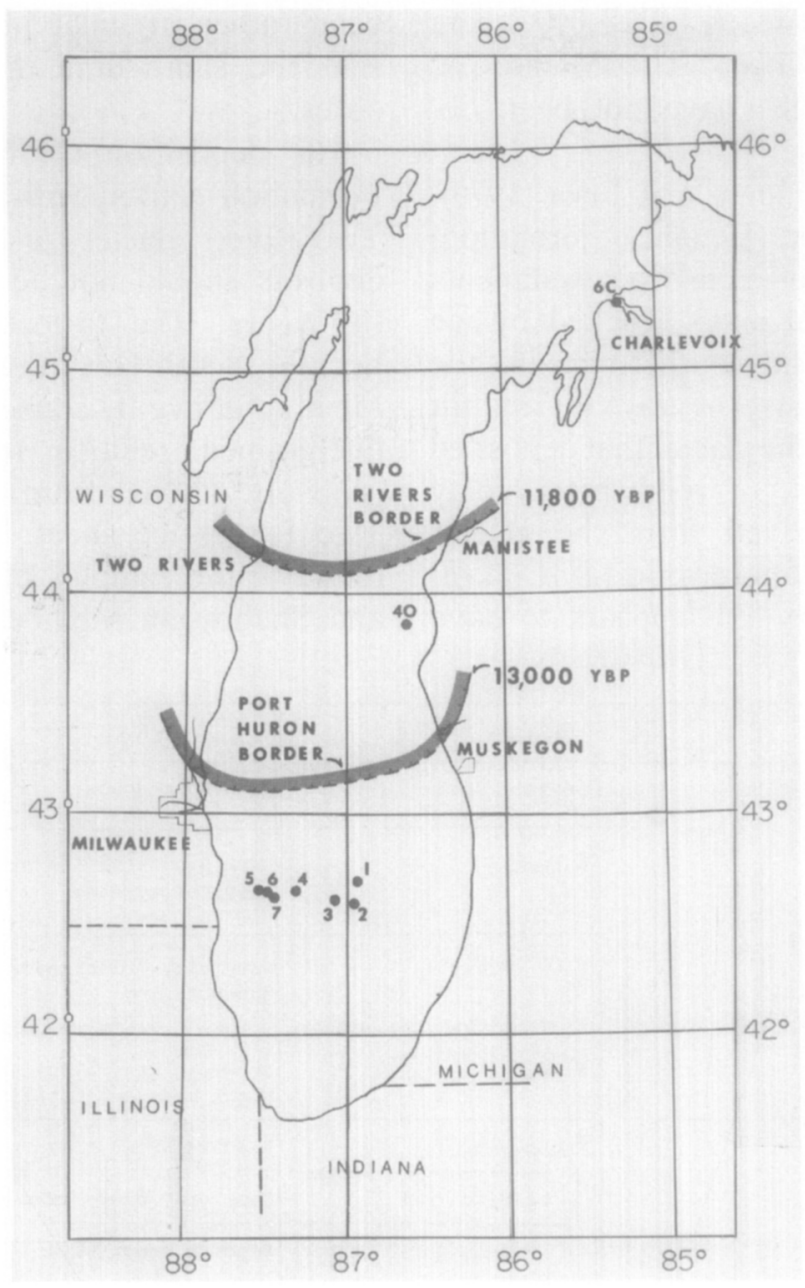

Fig. 1. Core locations in Lake Michigan. The water depth for cores 1-3 was over $500 \mathrm{ft}$ (165 m), for cores $4-40$ between 200 and $400 \mathrm{ft}$ (between 70 and $135 \mathrm{~m}$ ).

on field evidence, the age of the oldest known till unit that is found on the floor of the lake basin is about $13,500{ }^{14} \mathrm{C}$ years (Lineback et al., 1974). This till unit, the Wadsworth, is overlain by the Shorewood till representing a major ice advance around 13,000 years BP (Farrand et al., 1969). The general position of the ice front is indicated in Fig. 1 as the Port Huron front, though beds resembling the Shorewood till are found further south and appear to be present in two of our longest cores. The last readvance of the glacial lobe in Lake Michigan is probably represented by the Two Rivers ice front which overrode the Two Creeks Forest bed 11,800 ${ }^{14} \mathrm{C}$ years ago (Broecker and Farrand, 1963; Evenson, 1973). The Two Rivers till is found only north of Manistee and Two Rivers (Fig. 1). These tills, as well as the postglacial deposits, are shown in a general stratigraphic column in Fig. 2.

The Wadsworth Till Member, the lowest of the four tills underlying the lacustrine clays, is a gray silty-clayey till related to the moraines found at the southern end of the lake. Its age is about $13,500{ }^{14} \mathrm{C}$ years (Lineback et al., 1974). The reddishgray Shorewood Till Member probably represents Michigan's outer Port Huron 
morainic system, which is 13,000 years old or a little younger. The Manitowoc and Two Rivers tills have not been observed in our cores.

According to Willman and Frye (1970), the Carmi Member (Equality Formation) consists of glacial-lacustrine sediments deposited in glacial lakes blocked by ice sheets. Thus, in the southern basin, the Carmi Member consists of gray clay and silt when derived from the glacier that deposited the Wadsworth till, or reddish-gray clay and silt when derived from the glacier that deposited the Shorewood till. Deposition of the Equality Fm appears to have been rather irregular and may not represent the same time interval in different cores.

The deposition of the Lake Michigan Formation started with the waning of the Two Rivers glacier, and consequently the deposits should not be older than 11,800 ${ }^{14} \mathrm{C}$ years. The formation's basal member, the South Haven, and the Sheboygan Member above it, consist of homogeneous fine-grained reddish rock-flour material probably derived from the melting of the Two Rivers ice sheet. Varves have been found in the samples of the South Haven and Sheboygan Members in the northern

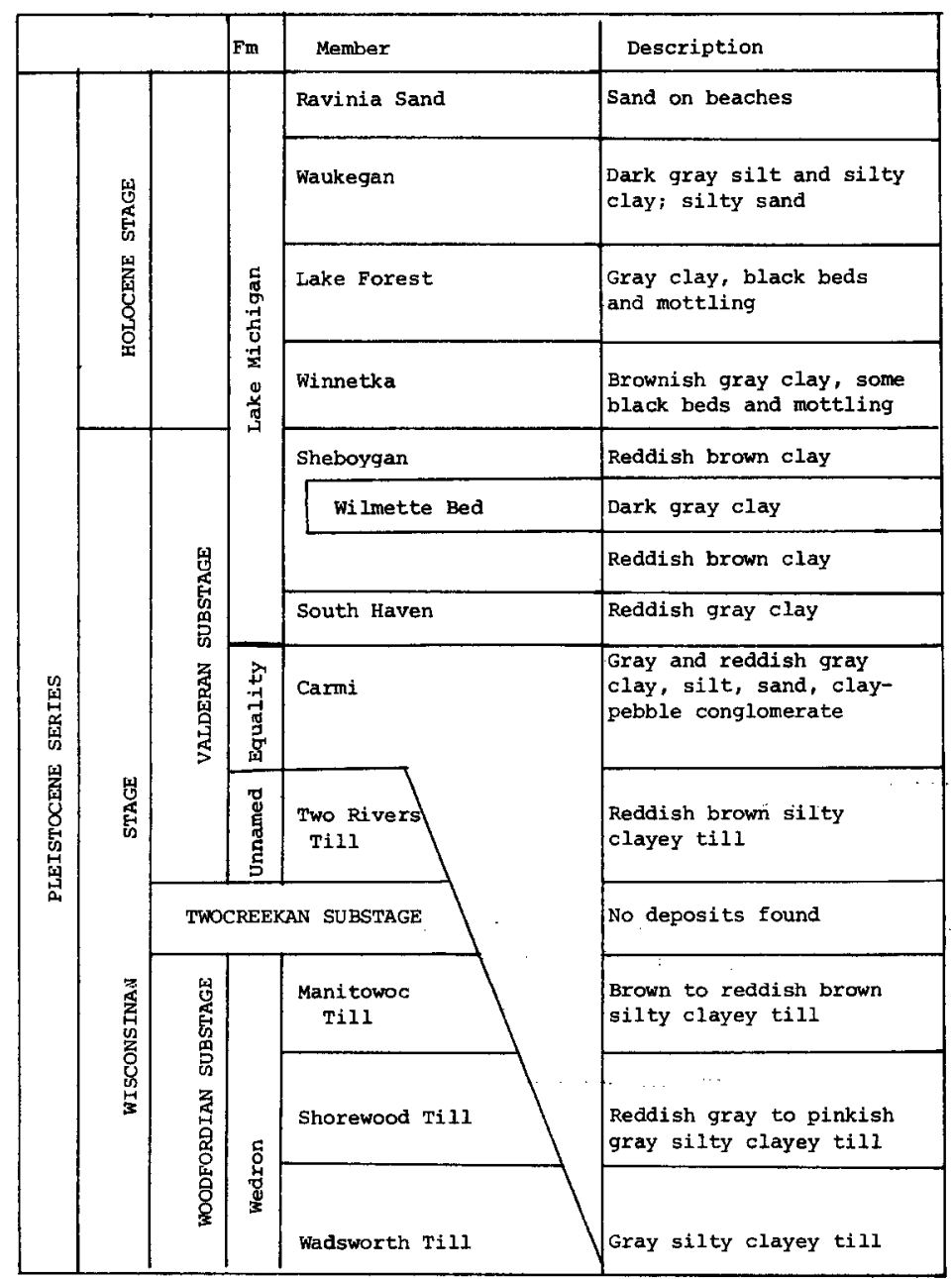

FIg. 2. Generalized stratigraphic column for late Pleistocene and Holocene sediments of southern and central Lake Michigan. From Lineback et al. (1974, p. 6). 


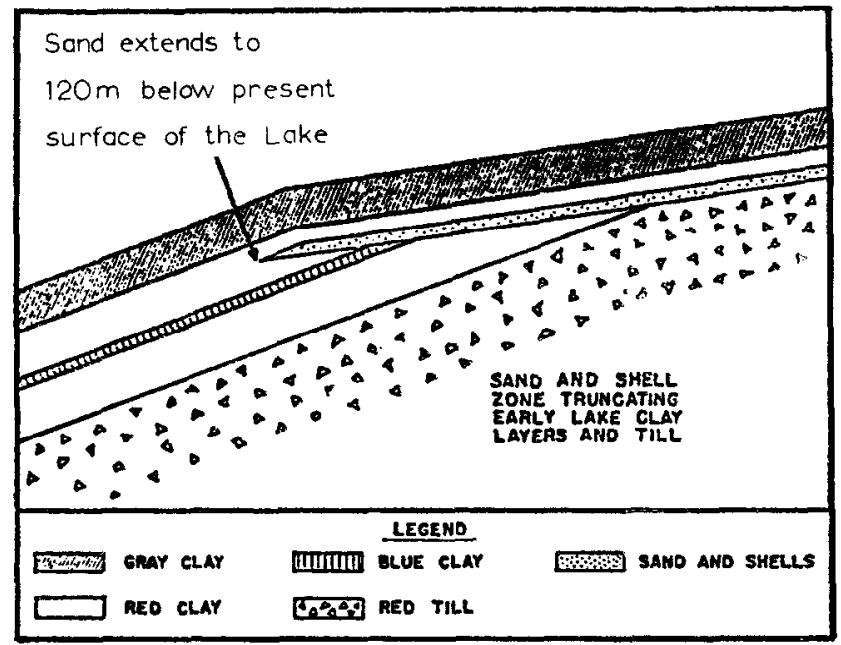

FIG. 3. Hough's (1955) schematic interpretation of core-sample logs, showing a sand-and-shells layer truncating part of the Lake Michigan Formation. The blue clay layer corresponds to the Wilmette bed of Fig. 2.

basin (Hough, 1955; Lineback et al., 1974). The South Haven and Sheboygan Members comprise more than $50 \%$ of our longest cores, whereas in the cores of Creer et al. (1976), younger members constitute the bulk of their material.

After retreat of the ice front from Lake Michigan, the water level oscillated due to the uncovering of a series of progressively lower outlets east of Georgian Bay. Opening of the North Bay outlet (Ontario) resulted in the eastward spilling of water of the Great Lakes, and in a general lowering of the lake levels. The opening of the North Bay Channel has been dated at $10,100 \pm 240$ and $10,870 \pm 130{ }^{14} \mathrm{C}$ years (Harrison, 1972). In Lake Michigan, the lowest level attained has been called the Chippewa low stage. A disconformity found by Hough (1955) in lake-bottom sediments where shallow-water layers truncate the normal deeper-water clays (Fig. 3), may be contemporaneous or possibly somewhat younger. Since this low stage occurred after the opening of the North Bay outlet, the disconformity (when observed) must be about $9000{ }^{14} \mathrm{C}$ years old, and can be placed stratigraphically above the Wilmette bed, a thin, darkgray bed contained in the Sheboygan Member (Fig. 2). Creer et al. (1976) as- signed a "magnetic" age of $8880{ }^{14} \mathrm{C}$ years to the Wilmette bed on the basis of a magnetic correlation with Lake Windermere sediments (Mackereth, 1971). The stratigraphy and composition of sediments of southern and central Lake Michigan have been extensively studied by members of the Illinois State Geological Survey and of the University of Wisconsin (Lineback et al., 1970, 1971, 1972, 1974; Gross et al., 1972) and the reader is referred to these papers for a detailed treatment.

The three younger members above the Sheboygan (the Winnetka, Lake Forest, and Waukegan Members) are dark colored, coarser, less poor in organic matter, and have a higher carbonate content than the underlying layers. Their sediments were perhaps derived from streams and by shoreline erosion of older tills and Paleozoic rocks. The Lake Forest Member has been dated at $7050 \pm 200{ }^{14} \mathrm{C}$ years (Lineback et al., 1970) and $6920 \pm 200{ }^{14} \mathrm{C}$ years (Lineback et al., 1972). The Waukegan Member has been dated at 3460 $\pm 210{ }^{14} \mathrm{C}$ years (Lineback et al., 1971) and at $910 \pm 140{ }^{14} \mathrm{C}$ years (Lineback et al., 1972). These dates are not very accurate due to the low content of organic material and due to the possible presence of older organic material derived from erosion 
of older deposits (Creer et al., 1976). In our cores, the three younger members of the Lake Michigan Formation are rather thin and not as well represented as in the cores studied by Creer et al. (1976).

\section{CORE COLLECTION AND SAMPLE PREPARATION}

The cores were obtained by letting a column of drill pipe $5 \mathrm{~cm}$ in diameter fall free so that the weight would drive the cutting edge through the lake sediments. This could result in a nonvertical direction of penetration. Other causes of undetected variations from the vertical, such as water currents or coring while the ship was drifting freely, have largely been avoided. In all these cases the mean remanent inclination would be likely to differ from core to core. This is not the case, however, since the mean inclination obtained from the various cores is $52^{\circ}$ for core $65-1,50.9^{\circ}$ for core $65-2,49.6^{\circ}$ for core $65-3$, and $49.7^{\circ}$ for core $6 \mathrm{C}$.

The pulling of the pipe from the bottom of the lake often resulted in sagging down of the bottom part of the core. Only the lowermost portions showed visible flow structures, possibly associated with the escaping of sediment down through the open lower end of the pipe. Results from these parts of the cores have been discarded. Since, in addition, the measured specimens were obtained from the central portions of the core, little chance remains that the reported inclinations and intensities of the remanent magnetization include disturbed sectors.

The sections of the pipe were disconnected and this resulted in a rotation of the core that was originally continuous and in the loss of a few tens of centimeters of core sediment. However, no flow structures were observed at the pipe segment breaks. The core was then extracted from the pipe sections, placed horizontally in half-cylinder holders, spliced lengthwise, and cut into $10-\mathrm{cm}$-long semicircular cylinders. The upper portions of the core that contained large amounts of water were discarded. Thus, the most recent part of the lake sediments is not well represented. The pipe segment breaks occur in the two longest cores only, and have been indicated by arrows in the core logs. In addition to these breaks, parts of core segments may have rotated internally relative to one another when the pipes were unscrewed, thereby affecting the declinations.

With the passing of time the core samples lost their water and now some of them show slight desiccation effects, such as cracks and warps. However, the overall dimensions of the core segments $(10 \mathrm{~cm}$ long, and $5 \mathrm{~cm}$ in diameter) did not change appreciably.

In the laboratory, a continuous series of cylindrical specimens was taken normal to the spliced core wall. The specimens were then sanded down to a size of 2.5 by $2.2 \mathrm{~cm}$. Thus care was taken to minimize possible edge effects due to the penetration of the pipe into the soft lacustrine sediments.

\section{MEASUREMENTS AND MAGNETIC PROPERTIES}

Magnetic measurements have been made with a Schonstedt (model SSM-1A) spinner magnetometer. Repeat measurements and demagnetization of specimens indicate a stable NRM (natural remanent magnetization). Stepwise alternating field (AF) demagnetization up to 1000 Oe in a Schonstedt AF demagnetizer and progressive thermal demagnetization up to $720^{\circ} \mathrm{C}$ resulted in small changes in direction for most specimens. A soft secondary magnetization, probably viscous remanence (VRM), was usually removed by a 100 200 Oe peak field.

In the upper left of Fig. 4 the graph shows the orthogonal projection of the intensity and direction changes of the magnetization during progressive AF demagnetization. As mentioned, there is a small change in the direction when a soft second- 


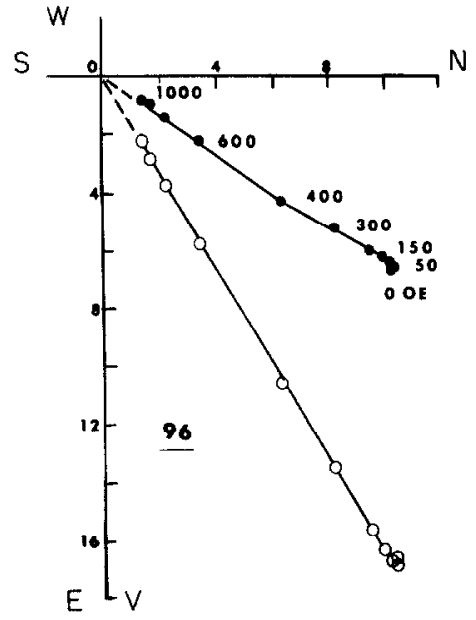

AF DEMAGNETIZATION

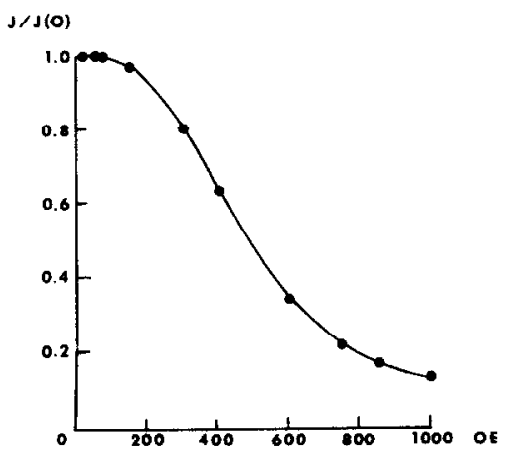

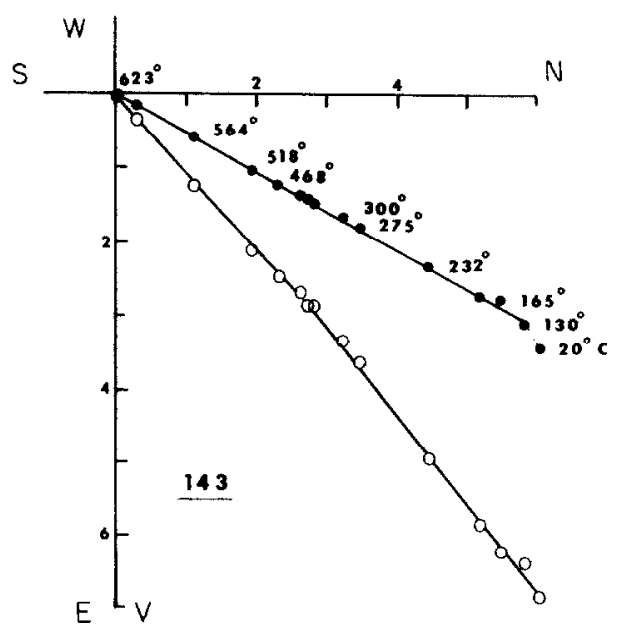

THERMAL

DEMAGNETIZATION

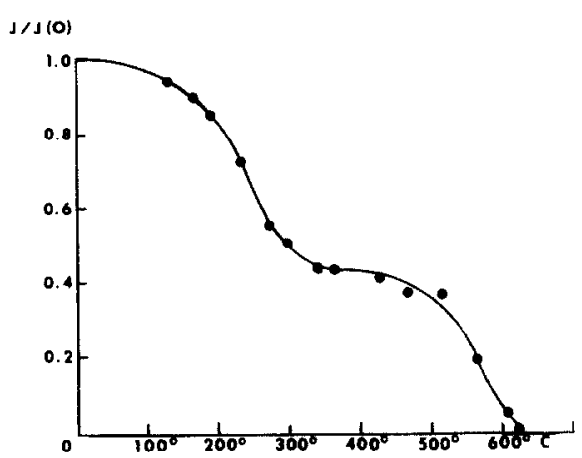

FIG. 4. Alternating field and thermal demagnetization diagrams for specimens 96 and 143 . The positions of these specimens are indicated in the core logs of Figs. 6-8. The upper two diagrams show the orthogonal projection of the end point of the magnetization vector during progressive demagnetization. Projections on the horizontal plane are represented by full symbols, projections on the $\mathrm{N}-\mathrm{S}$ vertical plane by open symbols. The two lower diagrams illustrate the corresponding changes in intensity of magnetization with increasing alternating peak field or temperature.

ary component of magnetization is removed by a 200 Oe peak value. After the initial change the direction of magnetization remains constant with further increase of the demagnetizing field up to 400 Oe. There is another, but very small change in direction at $400 \mathrm{Oe}$, whereupon the magnetization decays linearly towards the origin. The lower left diagram shows the changes of intensity with increasing $A F$, up to a maximum of $1000 \mathrm{Oe}$. Median coercive forces of about $400 \mathrm{Oe}$ are indicative of the bulk hardness and of the stability of the remanent magnetization in a majority of the samples.

The diagram in the upper right corner of Fig. 4 shows the projections during progressive thermal demagnetization of another specimen. The soft component of magnetization, possibly VRM, is removed at $130^{\circ} \mathrm{C}$. Another change in direction at $350^{\circ} \mathrm{C}$ indicates that here as well there are two slightly different components of magnetization. The diagram in the lower 
right shows, for the same specimen, the changes in intensity with increasing temperature. There are two blocking temperature ranges, one around $200-300^{\circ} \mathrm{C}$ and the other around $500-600^{\circ} \mathrm{C}$, corresponding to the two directions of magnetization. The component with the "harder" magnetization could be considered as the characteristic magnetization, though the difference is really small. Only 1 to $5 \%$ of the original magnetization remains after treatment of $600^{\circ} \mathrm{C}$, suggesting that the magnetization is carried by magnetite, primarily.

Two less typical examples are given in Fig. 5. The diagram on the left shows the elimination of one direction of magnetization below $200 \mathrm{Oe}$ as well as above $700 \mathrm{Oe}$. In the diagram on the right, the AF demagnetization is followed by thermal demagnetization (triangles) up to $700^{\circ} \mathrm{C}$. This demagnetization shows a marked change in direction at $700 \mathrm{Oe}$. In this case the "harder" magnetization is probably a secondary one, carried by hematite, and the "softer" magnetization is the characteristic magnetization, probably carried by magnetite. The latter two dia-

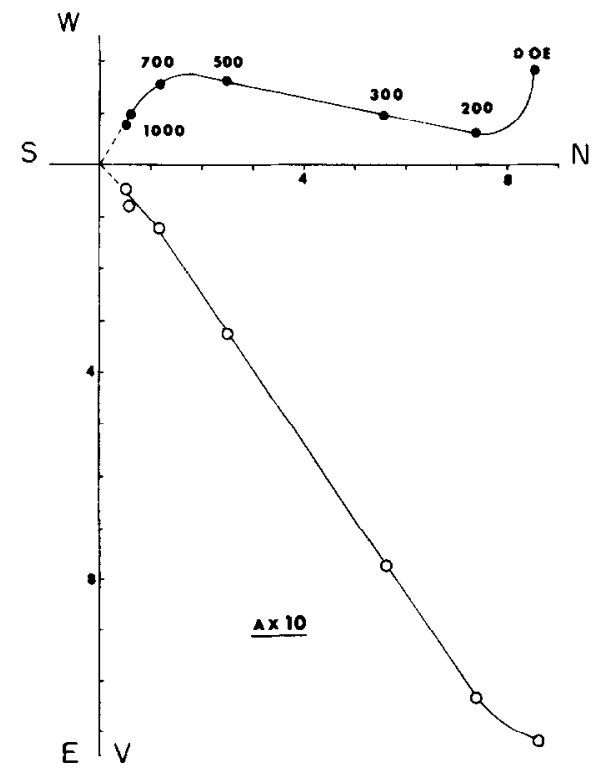

grams (Fig. 5) exemplify a few sediment specimens of the upper portion of the cores, indicated in Figs. 6-8, from the Winnetka Member of the Lake Michigan Formation, where stepwise AF and thermal demagnetization revealed two or more stable components of magnetization. Similar behavior was found in specimens from the Lake Forest and Waukegan Members. They demonstrate that these sediments have undergone additional postdepositional chemical changes.

The majority of the samples, however, showed only one stable component of magnetization, which is revealed after removal of VRM by AF or thermal demagnetization, and the behavior of the samples of Fig. 5 was rather atypical. In general, the correlation of the magnetic parameters between cores shows that the remanent magnetization was rapidly acquired, and became stabilized during or soon after the time of deposition. In most samples the magnetization has been almost unaffected by later changes in the ambient field, as shown by the relative unimportance of viscous components. Possible magnetic scatter, due to disturbance of the sedi-

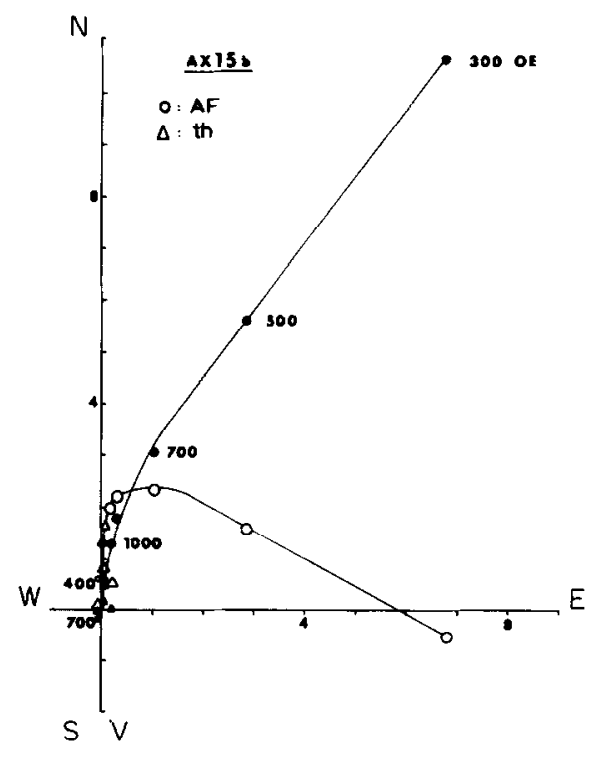

FIG. 5. Alternating field (AF) and AF/thermal demagnetization diagrams for samples from the uppermost part of core 65-1. The same convention as in Fig. 4. 


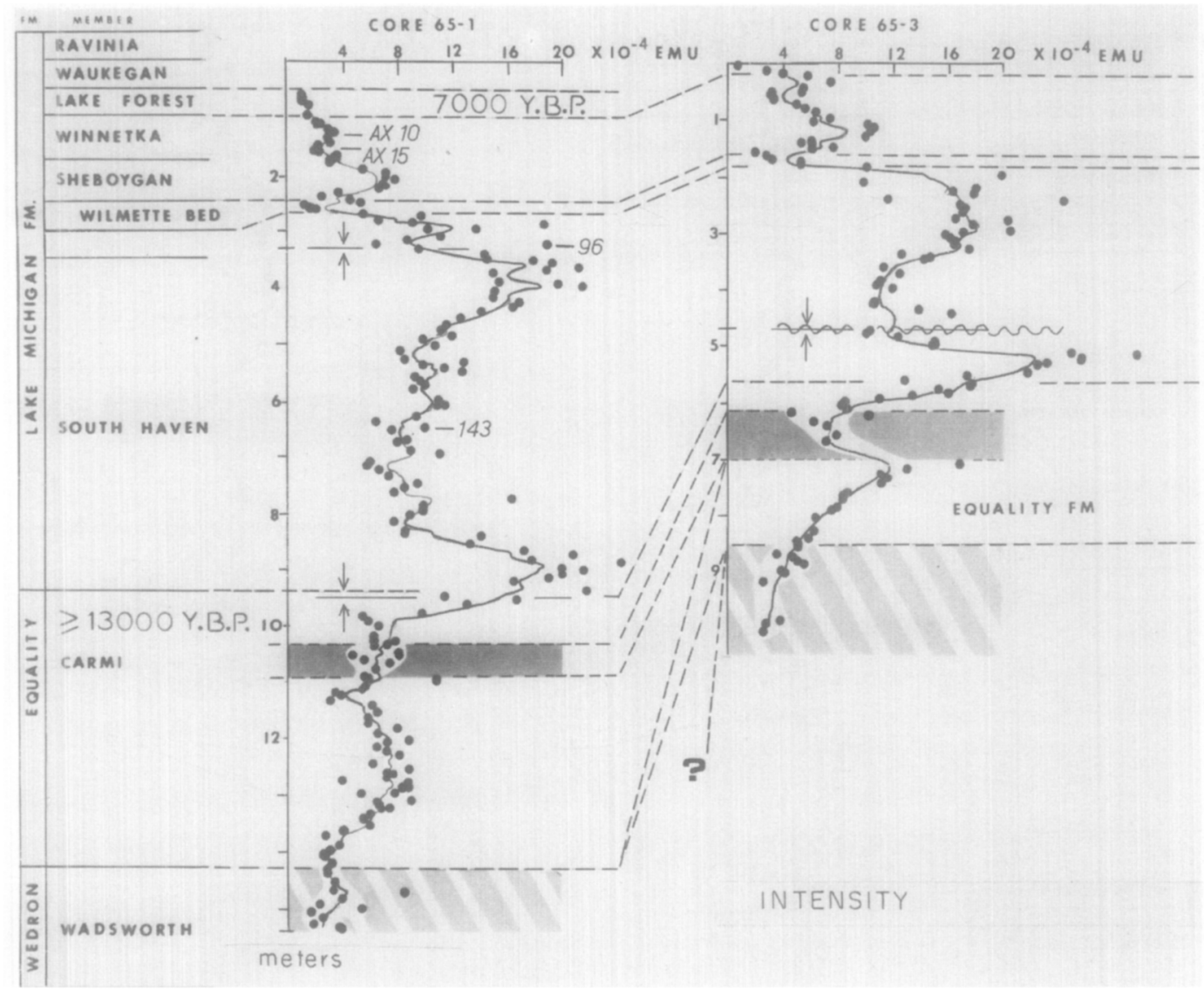

FIG. 6. Fluctuation of the untreated (NRM) intensity per sample with depth for the two longest cores (65-1 and 65-3). The column on the far left is from Fig. 2. Each point represents one specimen's measurement. Core segment breaks are indicated by arrows and a possible hiatus is shown in core 65-3 at about 5-m depth. Shaded areas represent the Shorewood (?) and Wadsworth tills, respectively.

ments during coring or to postdepositional movements, would of course persist even after demagnetization, and could be mistaken for excursions of the geomagnetic field (Verosub, 1975). We are confident, however, that these disturbances have been avoided.

\section{MAGNETOSTRATIGRAPHY}

The short-term fluctuations of the recorded inclination, declination, and intensity values of the specimens of cores 65-1 and 65-3 are illustrated in Figs. 6-8. These logs show the variations from the top of the cores, represented by the Lake Forest Member (about 7000 to $6000{ }^{14} \mathrm{C}$ years $\mathrm{BP}$ ), to the bottom of the cores, which reaches the Wadsworth till deposited about $13,500{ }^{14} \mathrm{C}$ years ago.

In these two longer cores a continuous normal polarity has been recorded. However, between the Lake Forest Member and the Wilmette bed (about $9000{ }^{14} \mathrm{C}$ years old) some of the inclinations are very low and some of them are negative (Fig. 7). There is a corresponding oscillation in declination in core 65-1 for the same specimens (Fig. 8). This oscillation in direction also appears in measurements on cores 65-5 and 65-6 (Fig. 9), and 6C (Fig. 10); the declination changes are gradual and appear to be real since no physical rotation phenomenon could be seen in cores $65-1,65-4,65-5,65-6$, or $6 \mathrm{C}$. Moreover, 


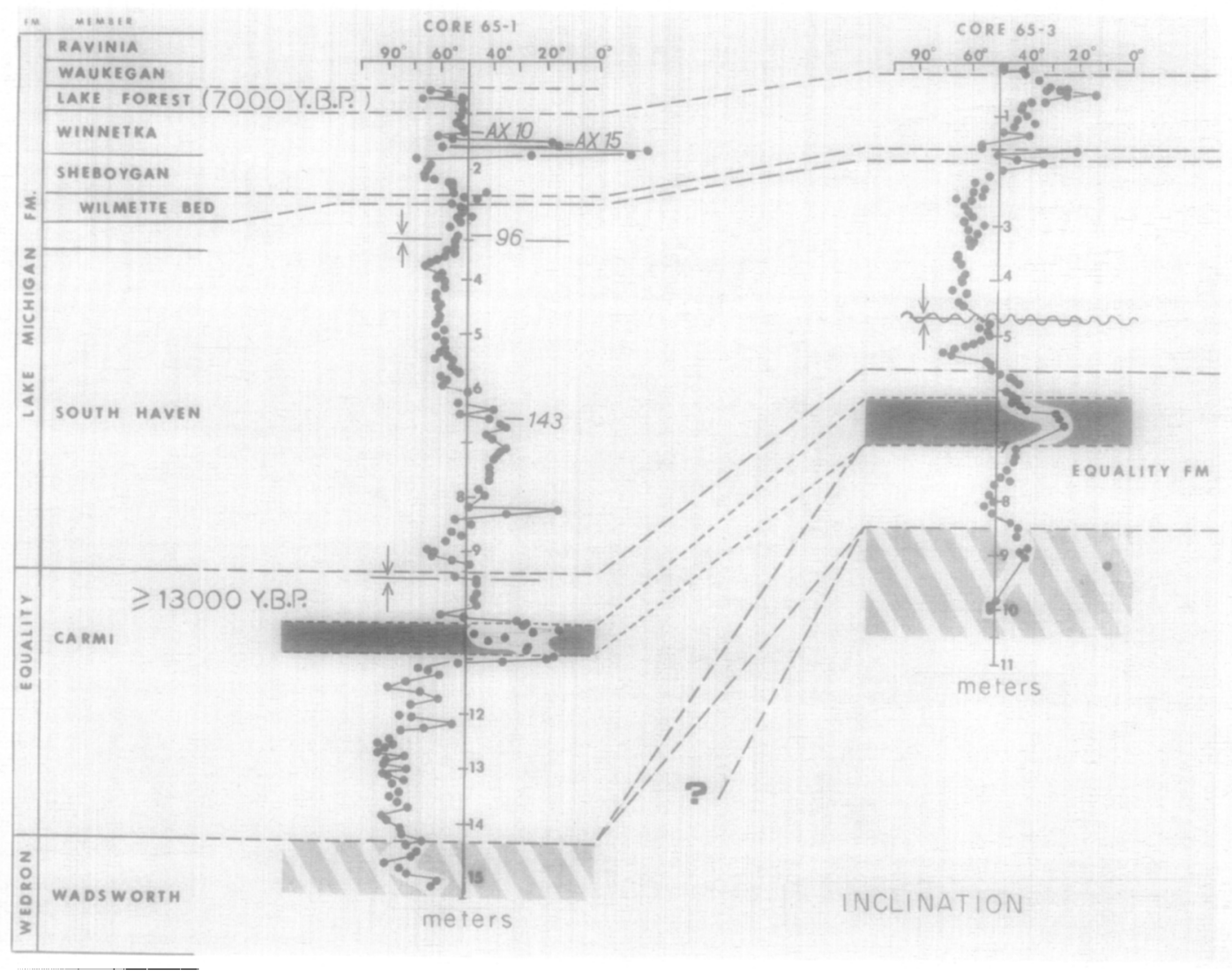

FIG. 7. Fluctuations of the inclination values in the two longest cores with depth. The inclinations are obtained after alternating field demagnetization up to 200 Oe or more.

in all these cases there is a gradual drop in sample intensity $(J)$ which is not related to lithological or observed mineralogical changes. We hesitate to ascribe these excursions to reversals or events since their virtual geomagnetic pole positions all fall in the northern hemisphere.

Since the cores were not oriented prior to extraction, the declination values are arbitrary. The longer cores (65-1, 65-3) consisted of more than one section. Uppermost sections have been set at an arbitrary zero average declination value, and the results of following sections have been rotated to form a continuous declination curve. A few instances remain where possibly undetected rotations are affecting the declination results, e.g., near the top of core 65-3 in Fig. 8.

We note that the basal Wadsworth till and the overlying diamicton bed, possibly corresponding to the Shorewood till, both give acceptable and consistent magnetic directions. It appears that tills are viable paleomagnetic recorders, despite their mode of deposition. This has been noted previously by Stupavsky et al. (1974). The diamicton bed (Shorewood?) within the Equality Formation of about 13,000 ${ }^{14} \mathrm{C}$ years also presents low inclination values (Fig. 7). However, evidence of the 12,350 years BP event, as documented by Mörner et al. (1971) and Mörner and Lanser (1974), has not been found.

Average inclinations for the cores were computed by taking the arithmetic mean. The average inclinations are shallow, about $+50^{\circ}$, as compared to the present-day magnetic inclination, $+74^{\circ}$, or to the inclination expected for a geocentric dipole 


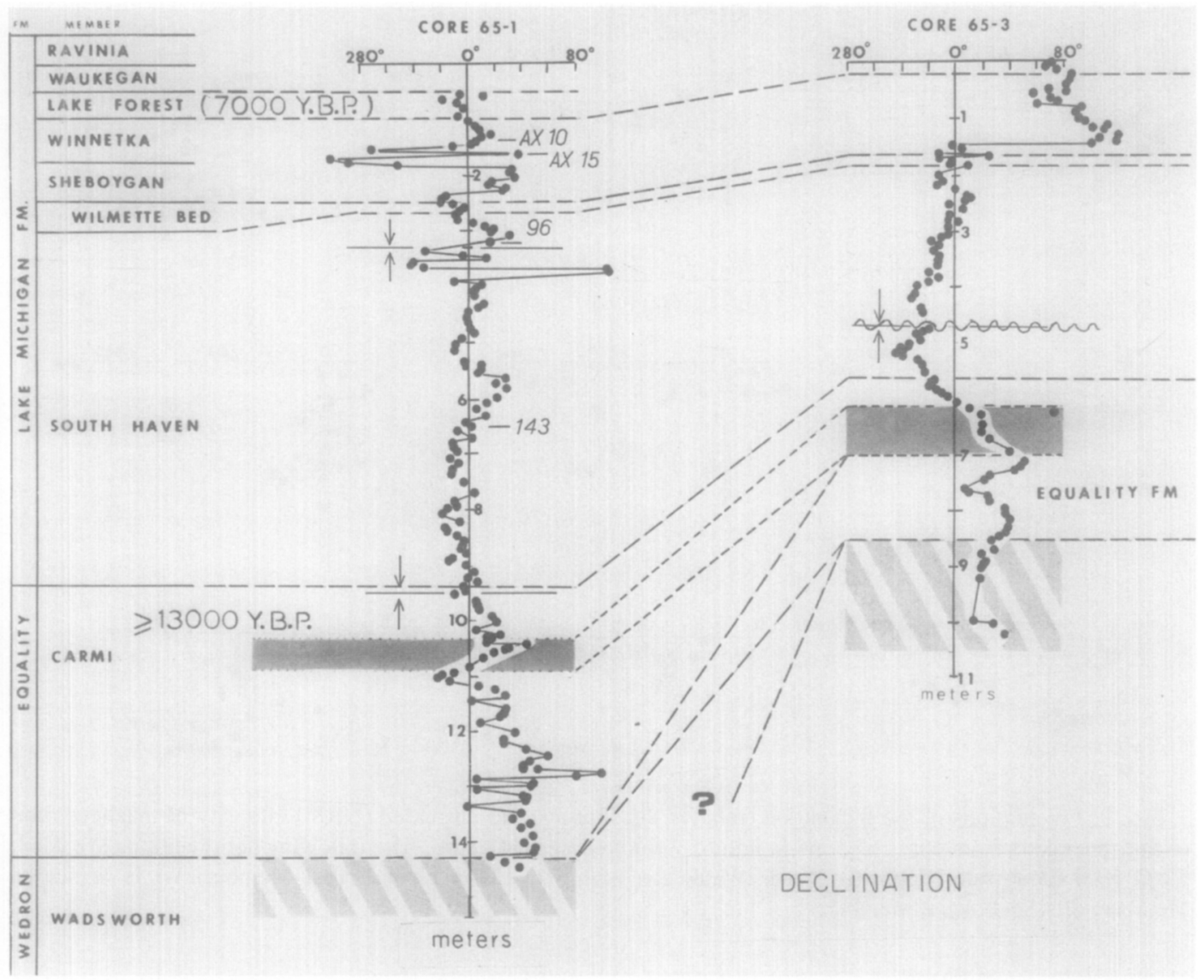

FIG. 8. Fluctuations of the declination values in the two longest cores with depth. The declinations are obtained after alternating field demagnetization up to $200 \mathrm{Oe}$ or more. Note that the declinations are relative only; core segments have been rotated so that the results form a continuous declination curve averaging zero degrees.

field, $+65^{\circ}$. This could possibly be attributed to "inclination error," due to compaction after deposition or preferential settling of elongated grains during deposition (King, 1955; Griffiths et al., 1960), but the deviation is very small when one ignores the anomalously low inclinations of the geomagnetic excursions. It is well known that arithmetic mean inclinations can be too high for unoriented cores taken at moderate to high latitudes (Briden and Ward, 1966). This can easily be seen in the example where the true inclination is $90^{\circ}$, whereas normal scatter results in dispersed directions with a mean inclination of less than $90^{\circ}$. This effect, plus the bias introduced by the anomalously low inclinations of the geomagnetic excursions, can be corrected for and would result in mean inclinations ranging between $58^{\circ}$ and $70^{\circ}$. A coaxial dipole shifted up along the rotation axis, instead of a geocentric dipole. as Wilson (1971) has suggested, also cannot be ruled out. Each member presents a characteristic inclination log. If water content controls the compaction suffered by a layer, the one with the least water presently most probably underwent the greatest compaction. Low water content was observed in the Wadsworth till and the Carmi Member (25 and 35\%, respectively, of dry weight), whereas all members above them have an average water content greater than $125 \%$ of dry weight. A too shallow 


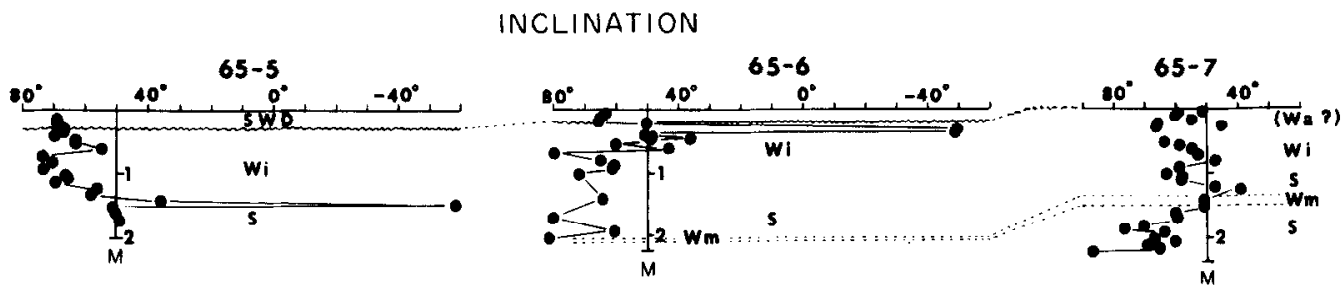

DECLINATION
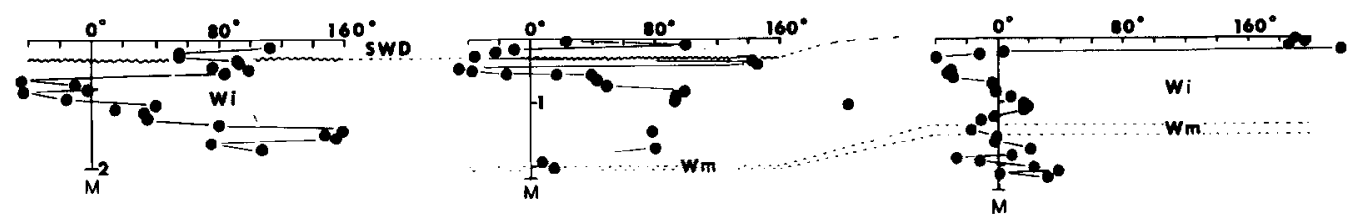

INTENSITY
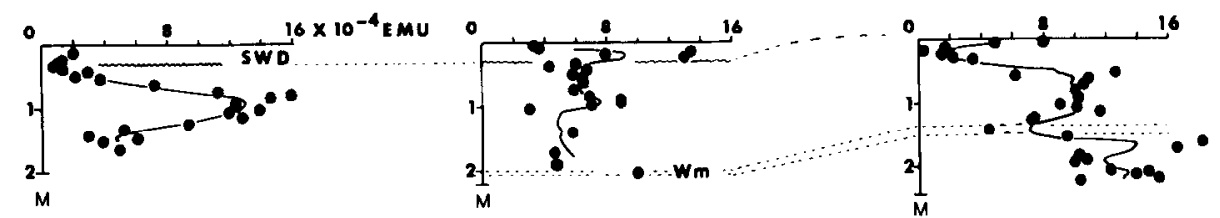

FIG. 9. Fluctuations of the inclination, relative declination, and untreated (NRM) intensity of magnetization of the specimens from cores 65-5, 65-6, and 65-7, plotted against depth. The following abbreviations are used: SWD is shallow-water deposits; Wa is Waukegan Member; LF is Lake Forest Member; Wi is Winnetka Member; $\mathbf{S}$ is Sheboygan Member.

inclination would then be expected for the Wadsworth till and Carmi Member. Just the opposite is observed (Fig. 7): despite their low water content, their inclinations are relatively high.
There is a direct relationship between intensity of the NRM of the specimens and the color of the sediments, which is related to the amount of organic material, the reducing conditions during deposition,

LAKE CHARLEVOIX (6C)
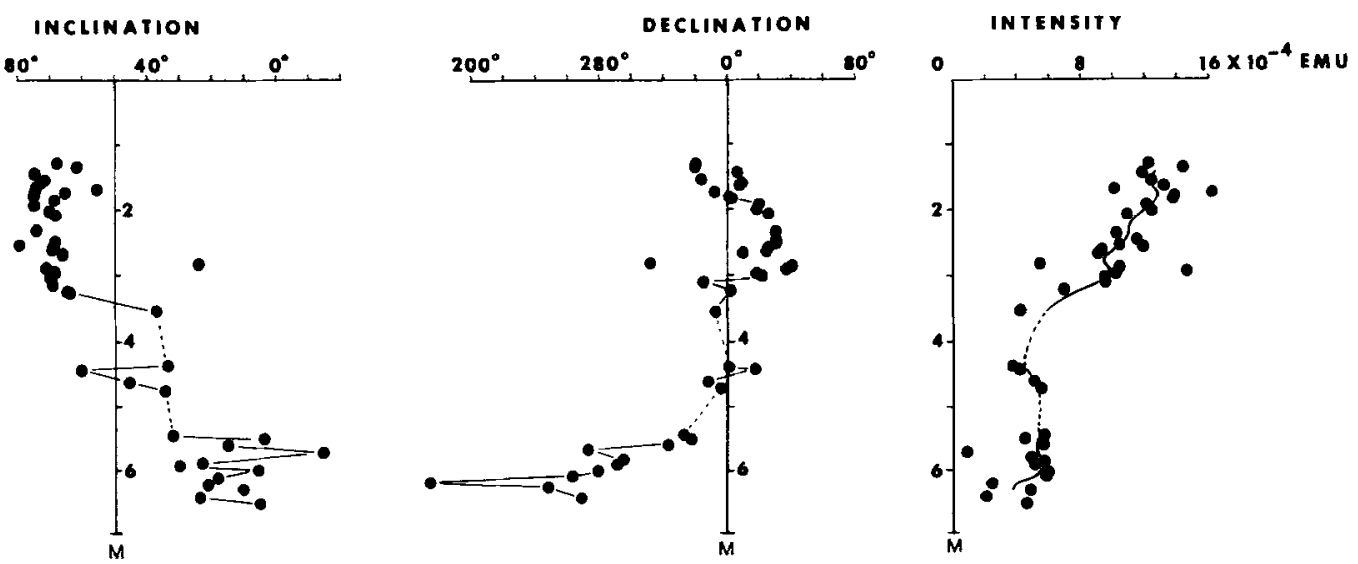

F1G. 10. Fluctuations of the inclination, relative declination, and untreated (NRM) intensity of the specimens from core 6C, from Lake Charlevoix (for location see Fig. 1). 

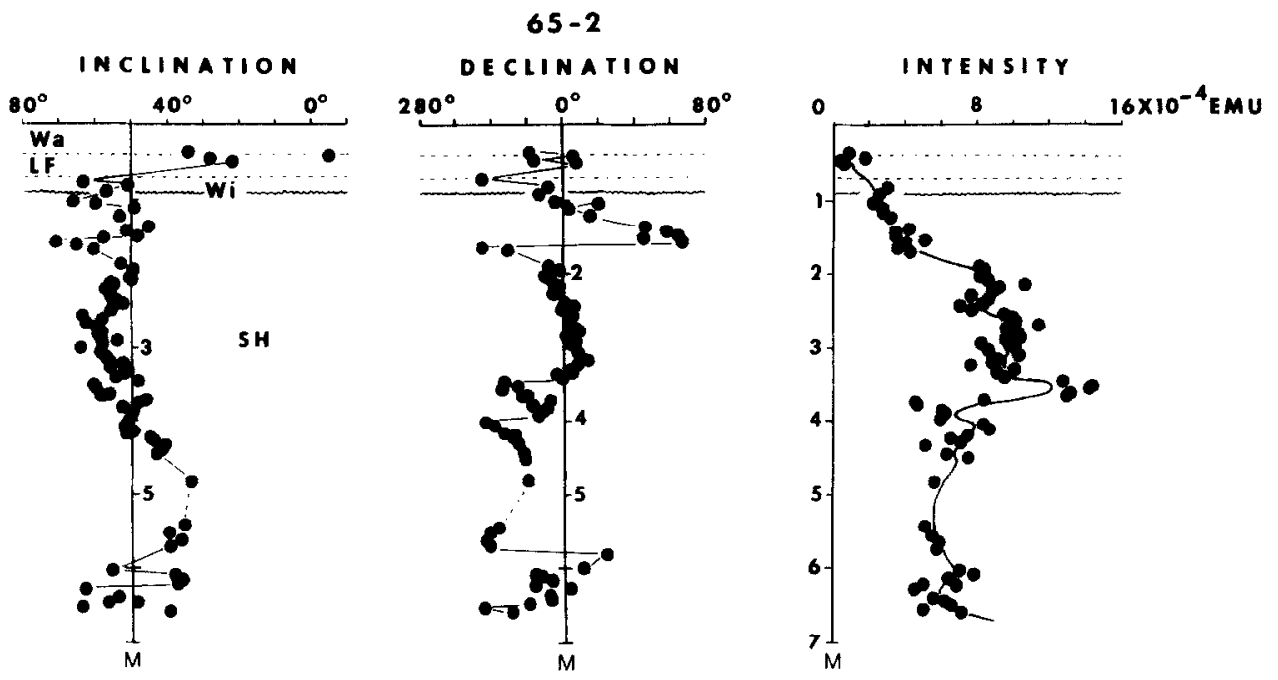

FIG. 11. Fluctuations of the inclination, relative declination, and untreated (NRM) intensity of the specimens from core 65-2, from southern Lake Michigan, plotted against depth. The following abbreviations are used: Wa is Waukegan Member; LF is Lake Forest Member; Wi is the Winnetka Member; SH is the South Haven Member.

and to the rate of sedimentation. This agrees with observations for Lake Windermere sediments in Great Britain (Thompson, 1973); he suggested that there is a direct relationship between carbon content and intensity. Thus during deposition of a normal sequence of postglacial lacustrine sediments, biological activity at the surface of deposition would affect the intensity of magnetization (Thompson, 1973).

The overall correlation between cores of their declination, inclination, and sample intensity is fairly good and agrees with independent lithostratigraphic determinations, as indicated by the dashed lines separating different members. In particular, the Sheboygan Member, the Wilmette bed, and the South Haven Member correlate well (Figs. 6-8, 11, 12). Note, for instance, that the sample intensity increases from the Sheboygan below the Wilmette bed to a peak value of $20 \times 10^{-4} \mathrm{emu}$ per sample in the upper part of the South Haven Member. Then it decreases to a low $6 \times 10^{-4}$ emu per sample in the middle South Haven, and forms another peak in the lower South Haven. Inclination and, to some extent, declination changes follow characteristic patterns. Inclination values for the South Haven Member vary from $65^{\circ}$ in the upper part to $30^{\circ}$ in the middle, and then back to $60^{\circ}$ in the lower part. Inclination values for the Carmi Member will vary with location since the deposition of this formation was time-transgressive northward. A local depositional hiatus above the Equality Formation appears as an interruption of the magnetic record in core 65-3 (Figs. 6-8). We have been able to detect magnetic interruptions in some of the other cores that have been lithologically conformed as local disconformities (Figs. 9, 11, 12).

The stratigraphic relationships between sediments from Lake Charlevoix (for location see Fig. 1) and Lake Michigan have yet to be worked out. However, correlating the magnetic record of Lake Charlevoix (Fig. 10) with those from southern Lake Michigan, we propose that the low inclination and sample intensity values shown near the bottom of core 6C (Fig. 10) correspond to the low values of the small excursion found in other cores in the Winnetka Member (e.g., Figs. 6, 7, 9, 11). The rate of sedimentation in Lake 
Charlevoix is clearly greater than the rate found in the southern part of Lake Michigan for this time.

\section{CONCLUSIONS}

The sediments of Lake Michigan are well magnetized and the direction of magnetization is generally stable in the sediments analyzed (Creer et al., 1976; this study). We believe that the magnetic fluctuations, in particular the inclinations, were well recorded in our cores of lacustrine clay, at about the time of deposition or shortly thereafter. The resolution of the record is good enough to detect secular variation and small excursions of the geomagnetic field. No reversals were found, but shallow inclination values were observed at two stratigraphic levels in several cores at about 7500 and $13,000{ }^{14} \mathrm{C}$ years BP.

Composite smoothed inclination, declination, and sample intensity curves were tentatively constructed using data from all Lake Michigan cores (Fig. 13). Although our primary goal for this research was to establish the feasibility of correlating magnetic signatures in parallel cores, we were encouraged by the results. These composite curves, however, should be considered preliminary until further Lake Michigan studies become available. The curves are arranged on a uniform time scale. The following time boundaries were used: base of Waukegan Member (5300 years BP),

\section{$65-40$}

65-4

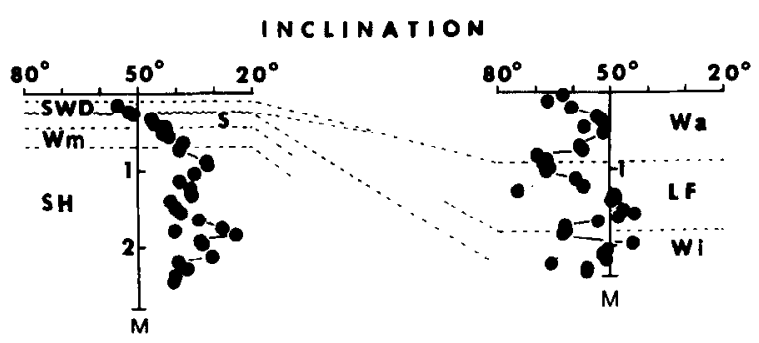

DECLINATION
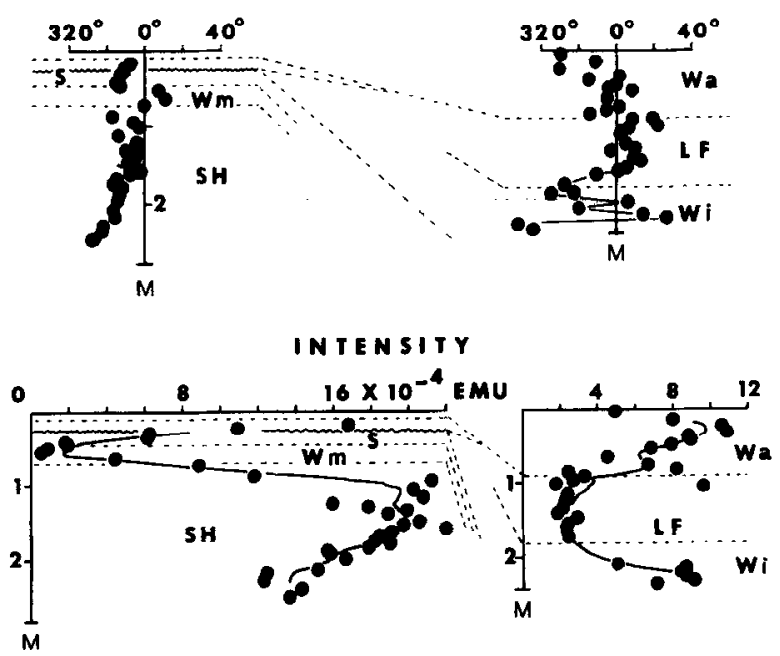

FIo. 12. Fluctuations of the inclination, relative declination, and untreated (NRM) intensity of the specimens from cores $65-40$ and $65-4$. The following abbreviations are used: SWD is shallow-water deposits; Wa is the Waukegan Member; LF is the Lake Forest Member; Wi is the Winnetka Member; Wm is the Wilmette bed; $\mathrm{S}$ is the Sheboygan Member; and SH is the South Haven Member. 


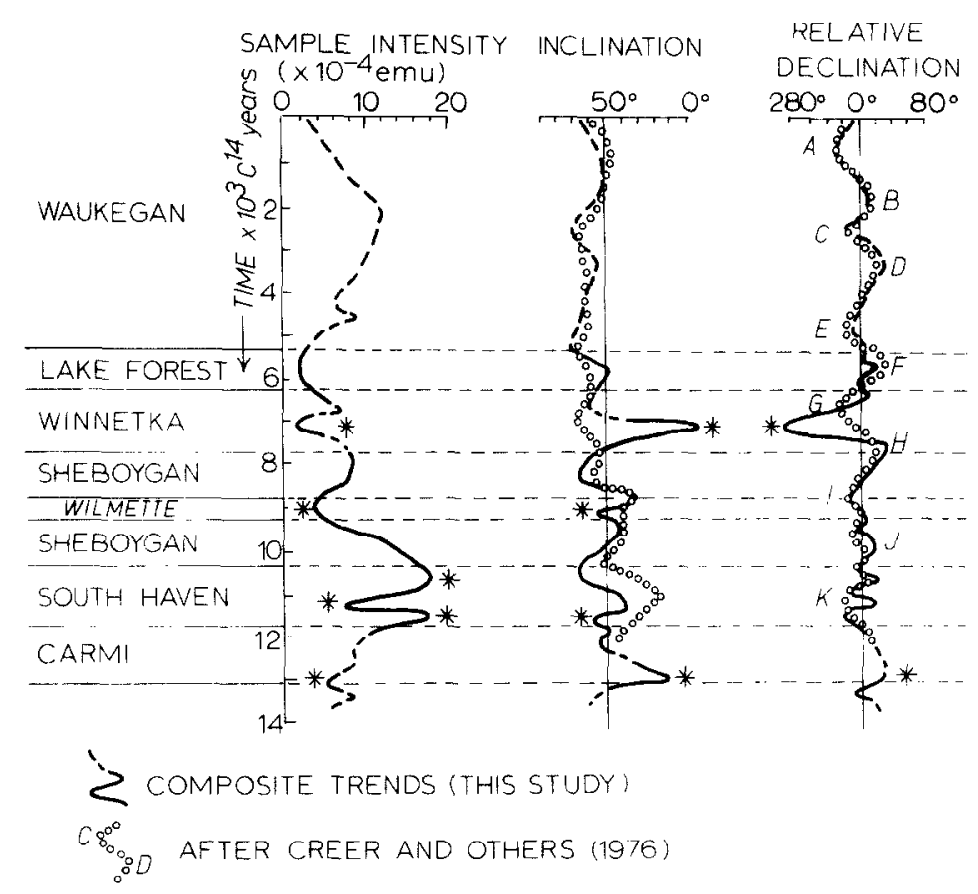

FIG. 13. Idealized composite curves for sample intensity, inclination, and relative declination; dashed were less well established. Markedly correlative features are indicated by asterisks. Curves from Creer et al. (1976) are shown for comparison. Results are plotted against a uniform time scale in radiocarbon years, rather than versus depth.

base of Lake Forest Member (6200 years BP), base of Wilmette bed (9200 years), base of South Haven Member $(11,800$ years), base of diamicton bed (Shorewood?) in the Carmi Member $(13,000$ years), and the bottom of the longest core $(13,500$ years).

The upper portion of the curves is based on sparse data because of the low sedimentation rates at the localities sampled. Our curves' maxima and minima do not correspond to well-defined dates, and for this time span we refer to the results of Creer et al. (1976), who obtained better resolution. The pattern of sample (NRM) intensity fluctuations does not necessarily correspond to the intensity of the geomagnetic field; yet, the upper portion of the curve is very similar to Cox's (1968) variation of the dipole moment of the geomagnetic field, based on archeomagnetic studies. The composite curve obtained by Opdyke et al. (1972) from deep-sea cores is also similar.
The best correlatable results were obtained from the lower part of our longest cores, in particular the Sheboygan and South Haven Members. They show a better resolution because of higher sedimentation rates shortly after the ice retreated from Lake Michigan. The NRM intensity curve appears to give the relative fluctuation of the ancient field, since the Sheboygan and South Haven Members have a rather homogeneous distribution of magnetic minerals.

In summary, these sediments provide a unique potential for a record of the magnetic field, that can be used for stratigraphic correlation and for future analyses of secular variation. But until more Lake Michigan results become available, we will refrain from attaching much significance to the periodicity in inclination and declination shown in Fig. 13.

\section{ACKNOWLEDGMENTS}

The cores were kindly supplied by Professor J. L. Hough of the University of Michigan. Invaluable 
discussions with Drs. George Kukla and Dennis Kent of Lamont-Doherty Geological Observatory improved the manuscript. The authors are indebted to Drs. W. R. Farrand, D. F. Eschman, H. N. Pollack (University of Michigan) and Dr. E. B. Evenson (Lehigh University) for suggestions and encouragement. We are grateful for the help given by Drs. E. B. Evenson, R. B. French, and by D. W. Williams and $\mathrm{J}$. Mitchell, in the coring and measuring of the specimens.

The measurements at the Paleomagnetic Laboratory of the University of Michigan were made possible by financial support of the H. H. Rackham School of Graduate Studies of the University of Michigan.

\section{REFERENCES}

Briden, J. C., and Ward, M. A. (1966). Analysis of magnetic inclination in boreholes. Pure and Applied Geophysics 63, 133-152.

Broecker, W. S., and Farrand, W. R. (1963). Radiocarbon age of the Two Creeks forest bed, Wisconsin. Geological Society of America Bulletin 74, 795-802.

Cox, A. (1968). Length of geomagnetic polarity intervals. Journal of Geophysical Research 73, 3247-3260.

Creer, K. M., Gross, D. L., and Lineback, J. A. (1976). Origin of regional geomagnetic variations recorded by Wisconsinan and Holocene sediments from Lake Michigan, U.S.A., and Lake Windermere, England. Geological Society of America Bulletin 87, 531-540.

Evenson, E. B. (1973). Late Pleistocene shorelines and stratigraphic relations in the Lake Michigan basin. Geological Society of America Bulletin 84, 2281-2298.

Farrand, W. R., Zahner, R., and Benninghoff, W. S. (1969). Cary-Port Huron Interstade: Evidence from a buried Bryophyte bed, Cheboygan county, Michigan. Geological Society of America Special Papers 123, 249-262.

Griffiths, D. H., King, R. F., Rees, A. I., and Wright, A. E. (1960). The Remanent Magnetization of some recent varved sediments. Proceedings of the Royal Society of London, Series A 256, $359-383$.

Gross, D. L., Lineback, J. A., Shimp, N. F., and White, W. A. (1972). Composition of Pleistocene sediments in southern Lake Michigan, U.S.A. In "International Geological Congress, 24th, Montreal 1972, Proceedings Section 8," pp. 215-222.

Harrison, J. E. (1972). Quaternary Geology of the North Bay-Mattawa Region." Geological Survey Canada Paper 71-26.

Hough, J. L. (1955). Lake Chippewa, a low stage of Lake Michigan, indicated by bottom sediments. Geological Society of America Bulletin 66, 957968.

King, R. F. (1955). The Remanent Magnetism of artificially deposited sediments. Monthly Notices of the Royal Astronomical Society, Geophysical Supplement 7, 115-134.

Lineback, J. A., Ayer, N. J., and Gross, D. L. (1970). "Stratigraphy of Unconsolidated Sediments in the Southern Part of Lake Michigan." Illinois Geological Survey Environmental Geology Note 35.

Lineback, J. A., Gross, D. L., Meyer, R. P., and Unger, W. L. (1971). "High-Resolution Seismic Profiles and Gravity Cores of Sediments in Southern Lake Michigan. Illinois Geological Survey Environmental Geology Note 47.

Lineback, J. A., Gross, D. L., and Meyer, R. P. (1972). "Geologic Cross Sections Derived from Seismic Profiles and Sediment Cores from Southern Lake Michigan." Illinois Geological Survey Environmental Geology Note 54.

Lineback, J. A., Gross, D. L., and Meyer, R. P. (1974). "Glacial Tills under Lake Michigan." Illinois Geological Survey Environmental Geology Note 69.

Mackereth, F. H. (1971). On the variation in direction of the horizontal component of remanent magnetization in lake sediments. Earth and Planetary Science Letters 12, 332-338.

Mörner, N.-A., and Lanser, J. P. (1974). Gothenburg magnetic "flip." Nature (London) 251, 408-409.

Mörner, N.-A., Lanser, J. P., and Hospers, J. (1971). Late Weichselian paleomagnetic reversal. Nature (London) 234, 173-174.

Opdyke, N. D., Ninkovich, D., Lowrie, W., and Hays, J. (1972). The paleomagnetism of two Aegean deep-sea cores. Earth and Planetary Science Letters 14, 145-159.

Stupavsky, M., Gravenor, C. P., and Symons, D. T. A. (1974). Paleomagnetism and magnetic fabric of the Leaside and Sunnybrook tills near Toronto, Ontario. Geological Society of America Bulletin 85, 1233-1236.

Thompson, R. (1973). Paleolimnology and paleomagnetism. Nature (London) 242, 182-184.

Verosub, K. L. (1975). Paleomagnetic excursions as magnetostratigraphic horizons: a cautionary note. Science 190, 48-50.

Willman, H. B., and Frye, J. C. (1970). "Pleistocene Stratigraphy of Illinois." Illinois Geological Survey Bulletin 94.

Wilson, R. L. (1971). Dipole offset: the time-average field over the last 25 million years. Geophysical Journal 22, 491-504. 